\title{
KAJIAN ARTIKEL: POTENSI PLASMA NON TERMAL SEBAGAI KANDIDAT TERAPI MASTITIS SUBKLINIS
}

\author{
Farah Alhamidah ${ }^{1}$, Yudit Oktanella ${ }^{1}$ Muhammad Khuzain ${ }^{2}$, Elfahra Casanza Amalda ${ }^{{ }^{*}}$ \\ ${ }^{1}$ Fakultas Kedokteran Hewan, Universitas Brawijaya \\ *Email: elfahracasanza@ student.ub.ac.id \\ ${ }^{2}$ Fakultas Teknik, Universitas Brawijaya
}

\begin{abstract}
Subclinical mastitis is the occurrence of inflammation in the parenchymal tissue of mammary glands due to bacterial contamination that does not show clinical symptoms lead to impacted on economic losses. The highest incidence of subclinical mastitis is the presence of Staphylococcus aureus bacteria contamination. Subclinical mastitis in Indonesia is reported to reduce milk production by up to 53.5\%. Pathogenesis of Staphylococcus aureus occurs in the presence of biofilm formation as bacterial immune system to protecting itself from disinfectants and antibiotics. In the last few decades, the development of plasma technology has been widely used in the medical field as cancer therapy, reducing pain, accelerating wound healing and tissue sterilization. There is no study that using the concept of utilizing Non Termal Plasma in the field of veterinary science, especially in mastitis therapy. Non Termal Plasma is able to decontaminate Staphylococcus aureus through inhibition and destruction of biofilms. The mechanism of action of Non Termal Plasma in repairing mammary gland tissue is through the destruction of DNA in the Reactive Oxygen Species (ROS) process by increasing the growth factor TGF- $\beta 1$ which accelerates the process normal cell regeneration. The objective of this study is to reviewing the efficacy of plasma non termal as subclinical mastitis theraphy. This study was conducted through a narrative review approach by collecting international and national literature with interval time of publication within 2010 - 2020.
\end{abstract}

Keywords: Subclinical Mastitis, Non Termal Plasma, Staphylococcus aureus.

\section{PENDAHULUAN}

Permasalahan utama dalam manajemen industri sapi perah adalah pengendalian penyakit mastitis yang berdampak besar terhadap kerugian ekonomi. Mastitis merupakan infeksi pada kelenjar mammae yang disebabkan oleh patogen pemicu respon inflamasi (Derakhshani et al., 2018). Manifestasi dari penyakit ini terdapat dua macam yaitu mastitis klinis dan subklinis (De Vliegher et al., 2012). Mastitis klinis ditandai dengan adanya peradangan ambing yang parah, sedangkan mastitis subklinis dikenali dengan adanya perubahan komposisi susu dan tingginya jumlah sel somatik (JSS) dalam waktu yang lama dan tanpa disertai gejala klinis sebelumnya (Kirsanova et al., 2019). Staphylococcus aureus merupakan bakteri utama penyebab mastitis subklinis. Bakteri gram positif ini diketahui dapat membentuk biofilm (Ren et al,. 2020). Biofilm merupakan penutup berbentuk lendir yang dihasilkan oleh bakteri untuk melindungi diri dari sistem kekebalan. Bakteri yang berada di dalam biofilm mampu bertahan terhadap antibiotik (Mirani et al., 2013), dan juga terhadap immunitas hospesnya (Toba et al., 2011). Infeksi bakteri Staphylococcus aureus pada ambing ternak perah dapat merugikan para peternak. Selain berakibat pada penurunan produksi susu, namun mastitis juga menyebabkan peningkatan jumlah cemaran bakteri dalam susu sehingga kualitasnya menjadi rendah dan ditolak pengumpul karena tidak memenuhi batas cemaran bakteri. Maksimum cemaran bakteri Staphylococcus aureus dalam susu menurut SNI No. 3141.1 : 2011 adalah sebesar $1 \times 10^{2} \mathrm{CFU} / \mathrm{ml}$.

Selama ini, cara yang umum digunakan untuk menangani infeksi Staphylococcus aureus penyebab mastitis subklinis adalah dengan menggunakan antibiotik. Namun di sisi lain, penggunaan antibiotik dapat menimbulkan galur-galur mikroba yang resisten (Ameen et al., 2020). Penggunaan antibiotik juga 
menyebabkan efek negatif lain berupa adanya residu antibiotik dalam susu (Kayitsinga et al., 2017). Keberadaan residu antibiotik dalam susu tidak hanya merugikan peternak, industri pengolahan susu, namun juga bagi para konsumen. Hal ini dikarenakan susu akan ditolak oleh pengumpul jika kadar residu antibiotik melebihi ambang batas maksimum sebagaimana yang tertuang dalam SNI 3141.12011 yaitu tidak boleh adanya cemaran antibiotik. Bagi yang mengonsumsinya, keberadaan antibiotik dalam susu dapat menimbulkan beberapa reaksi alergi, keracunan, sampai dengan syok. Selain itu, susu yang memiliki cemaran antibiotik tidak dapat digunakan dalam pembuatan produk fermentasi susu seperti keju dan susu. Oleh karena itu, dibutuhkan inovasi alternatif dan solutif dalam menangani mastitis subklinis tanpa menimbulkan efek resisten dan residu antibiotik (Detha, 2014).

Plasma non termal memiliki potensi untuk mengatasi masalah tersebut karena aktivitasnya dalam mendekontaminasi mikroorganisme. Teknologi plasma non termal merupakan cara dekontaminasi mikroorganime dengan memanfaatkan gas yang terionsasi dalam lucutan listrik antara dua elektroda (Lopes et al., 2013). Dalam beberapa dekade, penggunaan teknologi plasma banyak dilakukan di berbagai bidang medis seperti pada terapi kanker (Chang et al., 2014), mempercepat penyembuhan luka (Akimoto et al., 2016) dan juga sterilisasi jaringan (Nasir et al., 2016). Namun, belum ada studi yang menggunakan konsep pemanfaatan plasma non termal dalam bidang ilmu kedokteran hewan, misalnya pada proses penanganan mastitis. Berdasarkan studi sebelumnya penggunaan plasma non termal dalam bidang ilmu kedokteran mengindikasikan bahwa konsep ini juga dapat diterapkan menjadi kandidat terapi mastitis subklinis melalui reduksi Staphylococcus aureus. Mekanisme kerja plasma non termal dalam mereparasi jaringan kelenjar ambing adalah melalui penghancuran DNA dalam proses Reactive Oxygen Species (ROS) dengan meningkatkan ATM/p53 signalling pathway yang mempercepat proses apoptosis sel (Chang et al., 2014). Proses ini juga dapat mendekontaminasi Staphylococcus aureus melalui penghambatan dan penghancuran biofilm (Joshi et al., 2010). Plasma non termal dapat membunuh bakteri tanpa menggunkan antibiotik, sehingga tidak menimbulkan efek resisten dan juga residu antibiotik.

\section{METODE PENULISAN}

Metode penulisan dilaksanakan secara daring menggunakan metode penelitian kualitatif deskriptif melalui pendekatan Analisis Data Sekunder (ADS). Penelitian deskriptif yang digunakan bertujuan untuk menjelaskan alur berfikir dalam bentuk pembahasan narasi ilmiah. Data sekunder diperoleh dari berbagai literatur yang membahas penelitian terkait sebelumnya. Studi literatur yang digunakan bertujuan untuk mempelajari teori-teori yang berhubungan dengan sumber kajian penulisan. Pustaka yang digunakan yaitu buku-buku teks serta artikel ilmiah yang terbit pada interval waktu 20102020.

Ketika proses studi literatur, pengumpulan data dan analisis data telah dilakukan maka selanjutnya dilakukan penulisan artikel ilmiah dalam bentuk narrative review. Artikel dalam bentuk narrative review merupakan proses penyusunan teks dengan menggunakan survey berbagai sumber melalui artikel, buku dasn sumber lain yang relevan terhadap isu atau topik bahasan yang akan ditulis serta memberikan kesimpulan dan evaluasi kritis (Ramdhani et al., 2014).

\section{HASIL}

Melalui kajian beberapa studi literatur, kami membandingkan efektivitas reduksi $S$. aureus ketika diberi paparan plasma non termal dengan spesifikasi perangkat yang berbeda. Data perbandingan dapat dilihat pada tabel 1 .

Tabel 1. Perbandingan Efektivitas Plasma Non Termal dalam Reduksi S. aureus

\begin{tabular}{|c|c|c|c|}
\hline Sumber & $\begin{array}{c}\text { Perangkat } \\
\text { CAP }\end{array}$ & $\begin{array}{c}\text { Spesifi } \\
\text { kasi }\end{array}$ & Hasil \\
\hline $\begin{array}{l}\text { (Tian et } \\
\text { al., 2010) }\end{array}$ & $\begin{array}{c}\text { Cold } \\
\text { Atmospheri } \\
\text { c-Pressure } \\
\text { Air Plasma } \\
\text { Microjet } \\
\text { (PMJ) }\end{array}$ & $\begin{array}{c}5 \\
\text { menit, } \\
38^{\circ} \mathrm{C}, \\
550 \mathrm{~V}\end{array}$ & $\begin{array}{c}100 \% \\
\text { inaktivasi }\end{array}$ \\
\hline $\begin{array}{l}\text { (Fallon et } \\
\text { al., 2020) }\end{array}$ & $\begin{array}{c}\text { Cold } \\
\text { Atmospheri } \\
\text { c Plasma } \\
\text { (Udara) }\end{array}$ & $\begin{array}{c}5 \\
\text { menit, } \\
38^{\circ} \mathrm{C}, \\
30 \mathrm{kV}\end{array}$ & $\begin{array}{l}\text { Menghambat } \\
\text { kolonisasi } 3 \\
\text { log CFU/cm }{ }^{2} \\
\text { Menghambat } \\
\text { pembentukan }\end{array}$ \\
\hline
\end{tabular}




\begin{tabular}{|c|c|c|c|}
\hline & & & $\begin{array}{c}\text { biofilm } 66 \%- \\
78 \%\end{array}$ \\
\hline $\begin{array}{l}\text { (Thana et } \\
\text { al., 2019) }\end{array}$ & $\begin{array}{l}\text { Compact } \\
\text { Pulse- } \\
\text { Modulation } \\
\text { Cold Air } \\
\text { Plasma Jet }\end{array}$ & $\begin{array}{c}3 \\
\text { menit, } \\
<40^{\circ} \mathrm{C}, \\
2,52 \mathrm{kV}\end{array}$ & $\begin{array}{c}\text { Pada media } \\
\text { pertumbuhan } \\
\text { terbentuk area } \\
\text { inaktivasi } \\
\text { sebesar } 1,5 \\
\mathrm{~cm}^{2}\end{array}$ \\
\hline $\begin{array}{l}\text { (Lotfy et } \\
\text { al., 2020) }\end{array}$ & $\begin{array}{l}\text { Helium } \\
\text { Cold } \\
\text { Atmospheri } \\
\text { c Pressure } \\
\text { Plasma Jet } \\
\text { (HCAPPJ) }\end{array}$ & $\begin{array}{c}7 \\
\text { menit, } \\
38^{\circ} \mathrm{C}, \\
3,5 \mathrm{kV}\end{array}$ & $\begin{array}{c}99,9 \% \text { bakteri } \\
\text { mati }\end{array}$ \\
\hline $\begin{array}{c}\text { (Gök et } \\
\text { al., 2019) }\end{array}$ & $\begin{array}{c}\text { Cold } \\
\text { Atmospheri } \\
\text { c Plasma } \\
\text { (Oksigen) }\end{array}$ & $\begin{array}{c}3 \\
\text { menit, } \\
38^{\circ} \mathrm{C}, \\
25 \mathrm{kV}\end{array}$ & $\begin{array}{l}\text { Kemampuan } \\
\text { reduksi } 0.85 \\
\log \mathrm{CFU} / \mathrm{cm}^{2}\end{array}$ \\
\hline $\begin{array}{l}\text { (Olatund } \\
\text { e et al., } \\
2019)\end{array}$ & $\begin{array}{c}\text { High } \\
\text { Voltage } \\
\text { Cold } \\
\text { Atmospheri } \\
\text { c Pressure } \\
\text { Plasma } \\
\text { (HVCAP) }\end{array}$ & $\begin{array}{c}5 \\
\text { menit, } \\
38{ }^{\circ} \mathrm{C} \\
80 \\
\text { kVRM } \\
\text { S }\end{array}$ & $\begin{array}{c}\text { Suspensi } \\
\text { bakteri yang } \\
\text { awalnya } 6.0 \mathrm{log} \\
\text { CFU/ml turun } \\
\text { menjadi 3,78 } \\
\text { log CFU/ml }\end{array}$ \\
\hline $\begin{array}{l}\text { (Kniha et } \\
\text { al., 2020) }\end{array}$ & $\begin{array}{c}\text { Cold } \\
\text { Atmospheri } \\
\text { c Pressure } \\
\text { Air Plasma }\end{array}$ & $\begin{array}{c}3 \\
\text { menit, } \\
38^{\circ} \mathrm{C}\end{array}$ & $\begin{array}{c}\text { Kemampuan } \\
\text { reduksi } 2,2 \text { log } \\
\mathrm{CFU} / \mathrm{cm}^{2}\end{array}$ \\
\hline $\begin{array}{l}\text { (Laurita } \\
\text { et al., } \\
\text { 2017) }\end{array}$ & $\begin{array}{c}\text { Cold } \\
\text { Atmospheri } \\
\text { c Plasma }\end{array}$ & $\begin{array}{c}3 \\
\text { menit, } \\
38^{\circ} \mathrm{C}, \\
7,7 \mathrm{kV}\end{array}$ & $\begin{array}{l}\text { Kemampuan } \\
\text { reduksi hingga } \\
10^{3} \mathrm{CFU} / \mathrm{cm}^{2}\end{array}$ \\
\hline $\begin{array}{l}\text { (Al-rawaf } \\
\text { et } \\
\text { al.,2018) }\end{array}$ & $\begin{array}{c}\text { Non-Termal } \\
\text { Plasma Jet } \\
\text { (Helium) }\end{array}$ & $\begin{array}{c}15 \\
\text { menit, } \\
<34^{\circ} \mathrm{C} \\
7,5 \mathrm{kV}\end{array}$ & $\begin{array}{c}\text { Diameter zona } \\
\text { yang tidak } \\
\text { ditumbuhi } \\
\text { bakteri } 53,37 \\
\pm 0,8 \mathrm{~mm} \\
\end{array}$ \\
\hline $\begin{array}{c}\text { (Mohd } \\
\text { Nasir et } \\
\text { al., 2016) }\end{array}$ & $\begin{array}{l}\text { Dielectric } \\
\text { Barrier } \\
\text { Discharge } \\
\text { (Udara) }\end{array}$ & $\begin{array}{c}40 \mathrm{kV}, \\
50 \mathrm{~Hz}, \\
37^{\circ} \mathrm{C}\end{array}$ & $\begin{array}{c}\text { Inaktivasi } \\
\text { hampir } \\
\text { sepenuhnya } \\
\text { saat } 60 \text { menit }\end{array}$ \\
\hline $\begin{array}{l}\text { (Lunov et } \\
\text { al., 2016) }\end{array}$ & $\begin{array}{c}\text { Discharge } \\
\text { Plasma } \\
\text { Device }(\mathrm{He})\end{array}$ & $\begin{array}{c}0.5 \mathrm{kV}, \\
10 \mathrm{kV} \\
37^{\circ} \mathrm{C}\end{array}$ & $\begin{array}{l}\text { Durasi } 60 \\
\text { detik } \\
\text { mereduksi } \\
\text { bakteri }\end{array}$ \\
\hline $\begin{array}{l}\text { (Brun et } \\
\text { al., 2018) }\end{array}$ & $\begin{array}{c}\text { Discharge } \\
\text { Plasma } \\
\text { Device }(\mathrm{He})\end{array}$ & $\begin{array}{c}0.5 \mathrm{kV} \\
4.5 \\
\mathrm{MHz} \\
37^{\circ} \mathrm{C}\end{array}$ & $\begin{array}{c}\text { Inaktivasi } \\
\text { biofilm pada } 2 \\
\text { menit }\end{array}$ \\
\hline $\begin{array}{l}\text { (Belgace } \\
\text { m et al., } \\
2017)\end{array}$ & $\begin{array}{c}\text { Discharge } \\
\text { Plasma } \\
\text { Device (Ar, } \\
\left.\mathrm{O}_{2}, \mathrm{He}\right)\end{array}$ & $\begin{array}{c}0.5 \mathrm{kV}, \\
1.56 \\
\mathrm{MHz} \\
37^{\circ} \mathrm{C}\end{array}$ & $\begin{array}{c}\text { Reduksi } 6 \\
\log _{10} \text { pada } \\
\text { waktu } 10 \\
\text { menit } \\
\text { Gas paling } \\
\text { efektif } \mathrm{O}^{2} \\
\end{array}$ \\
\hline $\begin{array}{l}\text { (Carré et } \\
\text { al., 2018) }\end{array}$ & $\begin{array}{c}\text { Discharge } \\
\text { Plasma } \\
\end{array}$ & $\begin{array}{c}0.5 \mathrm{kV} \\
1.56\end{array}$ & $\begin{array}{c}\text { Reduksi pada } \\
\text { waktu } 120\end{array}$ \\
\hline
\end{tabular}

\begin{tabular}{|c|c|c|c|}
\hline & $\begin{array}{c}\text { Device }(\mathrm{Ar}, \\
\left.\mathrm{O}_{2}, \mathrm{~N}_{2}\right)\end{array}$ & $\begin{array}{l}\mathrm{MHz} \\
37^{\circ} \mathrm{C}\end{array}$ & menit \\
\hline $\begin{array}{c}\text { (Ziuzina } \\
\text { et al., } \\
2015)\end{array}$ & $\begin{array}{l}\text { Dielectric } \\
\text { Barrier } \\
\text { Discharge }\end{array}$ & $\begin{array}{c}80 \mathrm{kV}, \\
50 \mathrm{~Hz} \\
37^{\circ} \mathrm{C}\end{array}$ & $\begin{array}{c}\text { Durasi } \\
\text { minimal } 5 \\
\text { menit untuk } \\
\text { mereduksi }\end{array}$ \\
\hline $\begin{array}{l}\text { (Edelblut } \\
\text { e et al. } \\
2016)\end{array}$ & $\begin{array}{c}\text { Surface } \\
\text { Discharge } \\
\text { Plasma }\end{array}$ & $\begin{array}{c}10 \mathrm{kV}, \\
\mathrm{DC}, \\
500 \mathrm{~Hz}, \\
37^{\circ} \mathrm{C},\end{array}$ & $\begin{array}{c}\text { Kelembapan } \\
\text { berpengaruh } \\
\text { pada } 5 \text { menit } \\
\text { inaktivasi }\end{array}$ \\
\hline
\end{tabular}

\section{PEMBAHASAN}

\section{Efektivitas Plasma Non Termal dalam Inaktivasi Staphylococcus aureus}

Plasma non termal memiliki kemampuan mendekontaminasi bakteri Staphylococcus aureus. Mekanisme dan tingkat kemampuan dekontaminasi tersebut berbeda-beda tergantung jenis gas, waktu, serta kuat tegangan yang digunakan. Menurut Lofty et al., (2020), pemanfaatan helium sebagai gas carier dalam dekontaminasi S. aureus akan memberikan hasil maksimum karena dapat membunuh 99,9\% bakteri. Sedangkan menurut Tian et al., (2010), dekontaminasi menggunakan udara sebagai gas carier merupakan metode yang paling ideal karena dapat mengakibatkan $100 \%$ bakteri inaktivasi. Perbedaan hasil tersebut dikarenakan jenis gas yang digunakan. Penggunaan oksigen atau udara sebagai gas carier diketahui lebih efisien membunuh bakteri dari pada helium (Zhou et al., 2015), karena oksigen menjadi bahan baku dalam pembentukan Reactive Oxygen Species (ROS) yang merupakan agen efektif inaktivasi bakteri dalam plasma non termal (Sarron et al., 2012).

Selain jenis gas, kuat tegangan yang digunakan juga memengaruhi tingkat kemampuan plasma non termal dalam mendekontaminasi Staphylococcus aureus. Berdasarkan penelitian yang telah dilakukan oleh Gok et al., (2019) proses dekontaminasi menggunakan tegangan $3,5 \mathrm{kV}$ menghasilkan kemampuan reduksi sebesar $0,85 \log \mathrm{CFU} / \mathrm{cm}^{2}$ dan menurut Fallon et al., (2020) kemampuan reduksi sebesar $3 \log \mathrm{CFU} / \mathrm{cm}^{2}$ akan dihasilkan apabila tegangan yang digunakan sebesar 30 $\mathrm{kV}$. Hal tersebut dikarenakan intensitas dan pergerakan elektron akan bertambah seiring peningkatan tegangan yang digunakan (Zhang et al., 2017).

Faktor lain yang memengaruhi kemampuan dekontaminasi plasma non termal adalah lama waku pengaplikasian. Menurut 
Kniha et al., (2020) dekontaminasi dengan kurun waktu 3 menit menunjukkan hasil paling maksimum karena kemampuan reduksinya sebesar 2,2 $\log \mathrm{CFU} / \mathrm{cm}^{2}$, sedangkan menurut Fallon et al., (2020) dekontaminasi paling optimum dapat dicapai ketika pengaplikasian dilakukan selama 5 menit dengan kemampuan reduksi yang dihasilkan sebesar $3 \log \mathrm{CFU} / \mathrm{cm}^{2}$. Hal tersebut sesuai dengan pernyataan Olatunde et al., (2019) yang menyatakan bahwa kemampuan reduksi akan meningkat seiring lama waktu perlakuan. Semakin lama waktu pengaplikasian akan mengakibatkan pertambahan jumlah ion, uv, serta molekul radikal yang dihasilkan (Yadav et al., 2020). Sehingga efektivitas proses dekontaminasi juga mengalami peningkatan.

Selain dipengaruhi oleh teknik pembangkitan plasma, tingkat efisiensi inaktivasi bakteri $S$. aureus juga dipengaruhi oleh gas yang digunakan untuk mengahsilkan plasma dingin. Gas yang umum digunakan yakni oksigen, helium, argon, dan nitrogen. Tidak hanya itu, penelitian lain juga mengamati inaktivasi bakteri menggunakan sumber gas berupa udara (air). Gas atau udara tersebut ketika berada pada reaktor plasma akan terinonisasi dan menghasilkan plasma dingin. Penelitian Belgacem et al., (2017) dan Carre et al., (2018) menunjukkan bahwa tingkat inaktivasi bakteri tertinggi diperoleh pada penggunaan oksigen sebagai gas reaktor plasma. Perbedaan ini terlihat pada durasi perlakuan 15 menit, 30 menit, dan 45 menit. Namun, apabila durasi perlakuan plasma dingin diperpanjang, efisiensi dari inaktivasi bakteri dengan sumber gas yang berbeda akan menghasilkan perbedaan yang tidak signifikan.

Lucutan listrik tegangan tinggi dengan satuan kilo volt dapat mengionisasi udara ataupun gas dan membentuk plasma. Tingkat konsentrasi plasma yang terbentuk bergantung pada tinggi tendahnya tegangan yang digunakan. Semakin tinggi tegangan yang digunakan, konsentrasi ion pada plasma akan semakin tinggi pula. Sehingga, hal ini akan mempengaruhi tingkat inaktifasi bakteri. Pada penelitian Lunov et al., (2016), high voltage plasma $(10 \mathrm{kV})$ memberikan hasil yang cukup signifikan dibandingkan low voltage plasma $(0.5 \mathrm{kV})$.

Durasi perlakuan plasma dingin juga menjadi salah satu faktor yang mempengaruhi proses inaktivasi bakteri. Penelitian pada Tabel
1 menunjukkan bahwa semakin panjang durasi pemberian plasma dingin, tingkat inaktivasi bakteri akan semakin tinggi. Hal ini berlaku pada tiap metode pembangkitan plasma, gas maupun variasi tegangan listrik yang digunakan. Durasi perlakuan plasma dingin akan mempengaruhi tingkat paparan ion terhadap sel bakteri. Sehingga akan berakibat pada tingkat inaktivasi bakteri yang dihasilkan.

Faktor fisik lain yang mempengaruhi tingkat inaktivasi bakteri $S$. aureus yakni kelembapan permukaan media habitat bakteri. Penelitian Edelbute et al., (2016) mengamati tingkat inaktivasi bakteri $S$. aureus pada media yang berbeda. Hasil penelitian tersebut menunjukkan bahwa tingginya kelembapan dari media bakteri mengakibatkan tingkat inaktivasi akan semakin tinggi pula. Hal ini disebabkan adanya molekul air sebagai media penghantar dari ion plasma dingin.

\section{Mekanisme Plasma Non Termal dalam Dekontaminasi Staphylococcus aureus}

Plasma non termal memilki kemampuan efektif untuk mendekontaminasi bakteri. Hal ini dikarenakan plasma tersusun atas campuran partikel yang teronisasi, molekul radikal reaktif, dan juga ultraviolet (UV) (Sakudo et al., 2019). Salah satu molekul yang diemisikan oleh ultraviolet adalah NO (Nitrogen Oksida) (Tian et al., 2010). NO merupakan salah satu agen utama inaktivasi bakteri karena dapat menghancurkan sel dengan proses dimerisasi basa timin pada untaian DNA yang mengakibatkan terganggunya proses replikasi DNA. Selain Nitrogen Oksida, plasma non termal juga memproduksi beberapa molekul reaktif lainnya seperti $\cdot \mathrm{OH}, \cdot \mathrm{O} 2-$, dan $\mathrm{O} 3$. Molekul-molekul tersebut diketahui juga berperan dalam proses inaktivasi bakteri. Hidroksil radikal juga dapat membunuh bakteri dengan merusak asam lemak tak jenuh pada membran sel (Tian et al., 2010). •O2membantu pembentukan molekul radikal yang lebih reaktif, sedangkan O3 dapat menginterfensi respirasi seluler (Tian et al., 2010). Molekul protein penyusun membran sel bakteri diketahui rentan terhadap proses oksidasi sehingga pemberian perlakuan plasma non termal pada bakteri dapat menyebabkan erosi yang mengakibatkan pecahnya dinding sel bakteri. Selain menyebabkan pecahnya dinding sel, penggunaan plasma non termal juga dapat menghambat pembentukan serta 
menghancurkan biofilm melalui proses oksidasi oleh molekul reaktif pada permukaan dengan mengubah hidrofobisitasnya (Fallon et al., 2020).

\section{Konsep Terapi Mastitis Subklinis Berbasis Sterilisasi Plasma Non Termal}

Fase terjadinya mastitis subklinis terdiri atas fase invasi yang menyebabkan masuknya organisme patogen kedalam kanal ambing, kemudian terbentuk pertahanan pada jaringan epitel untuk memisahkan antara sel yang terinfeksi dengan yang tidak terinfeksi. Ketika sistem imunitas berusaha untuk menghancurkan patogen, maka jaringan normal akan mengeliminasi patogen pada fase awal sehingga terjadi inflamasi. Fase inflamasi diikuti dengan terjadinya infeksi pada kelenjar mammae, namun tidak menunjukkan gejala pada mastitis subklinis (Srivastava et al., 2015). $S$. aureus merupakan agen etiologis utama penyebab mastitis subklinis yang mampu mengakibatkan gejala perakut, akut, subakut dan kronis. Kondisi akut biasanya akan menimbulkan gangren yang berakibat pada tingginya angka mortalitas.

Pengobatan mastitis subklinis menggunakan teknologi plasma non termal didasari oleh beberapa studi sebelumnya yang membuktikan bahwa plasma memiliki kemampuan menginaktivasi S. aureus dengan perlakuan penyinaran plasma ke cawan petri yang berisi inokulasi $S$. aureus. Paparan plasma selama 15 menit dapat membuat zona hambat pada cawan petri melebar sebesar $53.37 \pm 0.8$ $\mathrm{mm}$ atau mereduksi S. aureus sebanyak 55\% (Al-rawaf et al., 2018). S. aureus merupakan bakteri gram positif yang memiliki yang memiliki struktur peptidoglikan sekitar 74-92\% daripada bakteri gram negatif sehingga akan mempengaruhi efektivitas paparan plasma. Perlakuan plasma pada S. aureus akan membutuhkan waktu paparan yang lebih lama karena perbedaan ketebalan membrane, struktur dan lapisan peptidoglikannya (Belgacem et al., 2017).

Mekanisme reduksi S. aureus pada mastitis subklinis menggunakan terapi plasma non termal diawali pada fase radiasi sinar UV pada materi genetik bakteri yang mana proses ini paling signifikan menurunkan aktivitas bakteri. Akumulasi radiasi sinar UV dapat menghancurkan dinding sel bakteri dengan melakukan penetrasi menuju penghancuran untai DNA melalui dimerisasi basa timin yang akan menghentikan proses replikasi bakteri, kemudian terjadi perpindahan partikel yang menginisiasi proses Reactive Oxygen Species (ROS) untuk menghancurkan membran bakteri dan memicu stress oksidatif yang mengarah kepada inaktivasi bakteri (Belgacem et al., 2017; Carré et al., 2018).

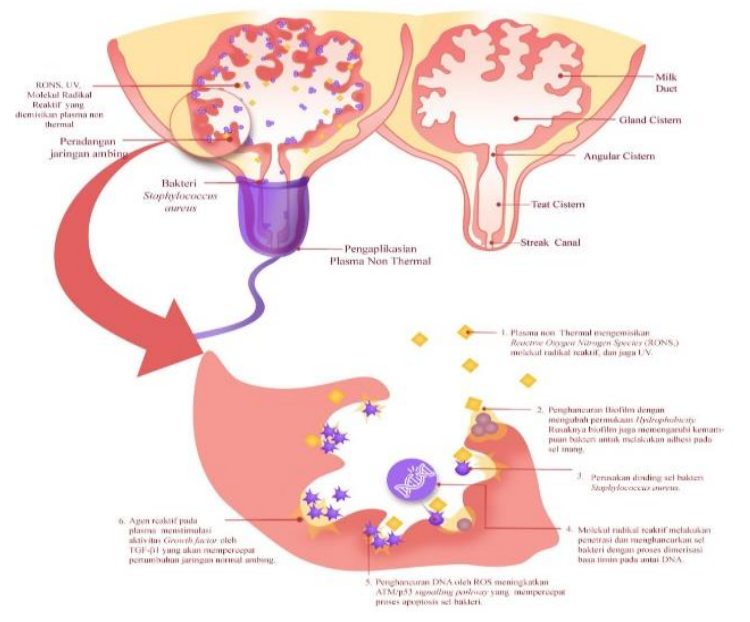

Gambar 1. Mekanisme Penyembuhan Mastitis Subklinis dengan Terapi Plasma Non Termal

Terdapat beberapa mekanisme yang mampu mengindikasikan efektivitas terapi plasma non termal dapat dilihat pada gambar 1 yaitu dengan adanya kemampuan menghancurkan biofilm (Hong et al., 2019; Joshi et al., 2010; Pandit et al., 2017), penghancuran DNA sel bakteri (Al-rawaf et al. 2018) serta percepatan proses pemulihan sel inflamasi (Akimoto et al., 2016; Bekeschus et al.,, 2016). Partikel tersebut akan menginvasi membran sel bakteri secara fisik serta menghancurkan Terapi plasma non termal memproduksi reagen spesies seperti $\mathrm{NO}, \mathrm{O}$, $\mathrm{OH}, \mathrm{H} 2 \mathrm{O} 2$ dan molekul lainnya yang berperan sebagai antimicrobial factor universal namun tidak menyebabkan perubahan patologis pada jaringan mukosa ataupun membunuh sel normal (Lotfy et al., 2020). Adanya reaktif spesies ini juga mengaktivasi MAPK pathway yang berperan dalam proses proliferasi sel yang mengalami inflamasi untuk menunjang pembentukan jaringan epidermis (Fathollah et al., 2016).

Studi yang dilakukan Kniha et al., (2020) menunjukkan bahwa terapi plasma non termal mampu menembus hingga $4 \mathrm{~mm}$ pada jaringan tulang, sehingga mengindikasikan bahwa paparan plasma tidak hanya efektif pada permukaan jaringan kulit namun bisa 
menembus hingga pada area dibawahnya. Perlakuan pada bakteri flora normal tidak menunjukkan terjadinya penurunan signifikan yang mengindikasikan bahwa susunan jaringan epitel mampu melindungi komponen mikroorganisme normal (Edelblute et al., 2016; Hong et al., 2019). Analisa histologis pada jaringan ikat juga menunjukkan bahwa sampel yang diberi perlakuan plasma tidak menunjukkan adanya perubahan struktur jaringan jika dibandingkan dengan variabel kontrol (Laurita et al., 2017).

Selama proses pemulihan sel yang mengalami inflamasi, terapi plasma non termal mampu menurunkan patogenesitas bakteri karena pembentukan hambatan ekstraseluler yang akan membantu proses penyembuhan dan mengurangi inflamasi (Bekeschus et al. 2016). Plasma kemudian memercepat proses apoptosis karena oksidasi yang kuat pada membran sel. Siklus sel merespon penghancuran DNA yang terjadi kemudian menstimulus dalam melakukan perbaikan sel atau mendorong proses terjadinya apoptosis. Agen reaktif pada plasma akan meningkatkan aktivasi growth factor oleh TGF- $\beta 1$ yang akan mempercepat pertumbuhan jaringan normal (Fathollah et al. 2016).

\section{KESIMPULAN}

Plasma merupakan fase zat keempat yaitu gas yang terionisasi. Reaktif spesies pada paparan plasma non termal berupa oksigen ataupun nitrogen memiliki peran sebagai antimicrobial factor yang mampu menghambar proses pembentukan biofilm serta menghancurkan DNA sel bakteri. Plasma mampu menurunkan patogenesitas bakteri dengan membentuk hambatan ekstraseluler yang akan mengurangi inflamasi kemudian mendorong terjadinya apoptosis serta meningkatkan aktivasi growth factor oleh TGF$\beta 1$ yang mempercepat pertumbuhan jaringan normal pada kelenjar mammae. Melalui analisis data sekunder yang digunakan, mekanisme kerja plasma non termal memiliki potensi untuk diaplikasikan pada bidang medik veteriner sebagai kandidat terapi mastitis subklinis dengan mempertimbangkan spesifikasi alat plasma non termal yang digunakan.

\section{REFERENSI}

Akimoto, Y., Ikehara, S., Yamaguchi, T., Kim, J., Kawakami, H., Shimizu, N., ... Ikehara, Y. 2016. Galectin expression in healing wounded skin treated with lowtemperature plasma: Comparison with treatment by electronical coagulation. Archives of Biochemistry and Biophysics, 605, 86-94.

Al-rawaf, A. F., Fuliful, F. K., Khalaf, M. K., \& Oudah, H. K. 2018. Studying the nontermal plasma jet characteristics and application on bacterial decontamination. Journal of Theoretical and Applied Physics, 12, 45-51.

Ameen, Fuad, Alshehri, W. A., \& Nadhari, Saleh Al. 2020. Effect of Electroactive Biofilm Formation on Acetic Acid Production in Anaerobic Sludge Driven Microbial Electrosynthesis. ACS Sustainable Chemistry \& Engineering, 8, 311-318.

Bekeschus, S., Schmidt, A., Weltmann, K. D., \& von Woedtke, T. 2016. The plasma jet kINPen - A powerful tool for wound healing. Clinical Plasma Medicine, 4, 1928.

Belgacem, Z. Ben, Carre, G., Charpentier, E., Le-Bras, F., Maho, T., Robert, E., ... Gelle, M. P. 2017. Innovative non-termal plasma disinfection process inside sealed bags: Assessment of bactericidal and sporicidal effectiveness in regard to current sterilization norms. PLOS ONE, $12,1-18$.

Brun, P., Bernabè, G., Marchiori, C., Scarpa, M., Zuin, M., Cavazzana, R., ... Martines, E. 2018. Antibacterial efficacy and mechanisms of action of low power atmospheric pressure cold plasma: membrane permeability, biofilm penetration and antimicrobial sensitization. Journal of Applied Microbiology, 125, 398-408.

Badan Standarisasi Nasional. 2011. Standar Nasional Indonesia (SNI) 01-3141-2011 tentang Syarat Mutu Susu Segar. Dewan Standarisasi Nasional. Jakarta, 52.

Carré, G., Charpentier, E., Audonnet, S., Terryn, C., Boudifa, M., Doliwa, C., ... 
Gelle, M. P. 2018. Contribution of fluorescence techniques in determining the efficiency of the non-termal plasma treatment. Frontiers in Microbiology, 9, $1-12$.

Chang, J. W., Kang, S. U., Shin, Y. S., Kim, K. Il, Seo, S. J., Yang, S. S., ... Kim, C. H. 2014. Non-termal atmospheric pressure plasma induces apoptosis in oral cavity squamous cell carcinoma: Involvement of DNA-damage-triggering sub-G1 arrest via the ATM/p53 pathway. Archives of Biochemistry and Biophysics, 545, 133140.

De Vliegher, S., Fox, L. K., Piepers, S., McDougall, S., \& Barkema, H. W. 2012. Invited review: Mastitis in dairy heifers: Nature of the disease, potential impact, prevention, and control. Journal of Dairy Science, 95, 1025-1040.

Derakhshani, H., Fehr, K. B., Sepehri, S., Francoz, D., De Buck, J., Barkema, H. W., ... Khafipour, E. 2018. Invited review: Microbiota of the bovine udder: Contributing factors and potential implications for udder health and mastitis susceptibility. Journal of Dairy Science, 101, 10605-10625.

Detha, A. I. R. 2014. Pengujian Residu Antibiotik Pada Susu. Jurnal Kajian Veteriner, 2(2), 203-208.

Edelblute, C. M., Malik, M. A., \& Heller, L. C. 2016. Antibacterial efficacy of a novel plasma reactor without an applied gas flow against methicillin resistant Staphylococcus aureus on diverse surfaces. Bioelectrochemistry, 112, 106111.

Fallon, M., Boyle, M., Kennedy, S., Daniels, S., \& Humphreys, H. 2020. Cold atmospheric plasma, the removal of blood from steel and its effect on staphylococcal biofilm formation. A pilot study. Clinical Plasma Medicine, 19-20, 100104.

Fathollah, S., Mirpour, S., Mansouri, P., Dehpour, A. R., Ghoranneviss, M., Rahimi, N., ... Chalangari, K. M. 2016. Investigation on the effects of the atmospheric pressure plasma on wound healing in diabetic rats. Scientific Reports, 6. https://doi.org/10.1038/srep19144
Gök, V., Aktop, S., Özkan, M., \& Tomar, O. 2019. The effects of atmospheric cold plasma on inactivation of Listeria monocytogenes and Staphylococcus aureus and some quality characteristics of pastırma-A dry-cured beef product. Innovative Food Science and Emerging Technologies, 56, 102188.

Hong, Q., Dong, X., Chen, M., Sun, H., Hong, L., Wang, Y., ... Yu, Q. 2019. An in vitro and in vivo study of plasma treatment effects on oral biofilms. Journal of Oral Microbiology,

11. https://doi.org/10.1080/20002297.2019.16 03524

Joshi, S. G., Paff, M., Friedman, G., Fridman, G., Fridman, A., \& Brooks, A. D. 2010. Control of methicillin-resistant Staphylococcus aureus in planktonic form and biofilms: A biocidal efficacy study of nontermal dielectric-barrier discharge plasma. American Journal of Infection Control, 38, 293-301.

Kayitsinga, J., Schewe, R. L., Contreras, G. A., \& Erskine, R. J. 2017. Antimicrobial treatment of clinical mastitis in the eastern United States: The influence of dairy farmers' mastitis management and treatment behavior and attitudes. Journal of Dairy Science, 100, 1388-1407.

Kirsanova, E., Heringstad, B., LewandowskaSabat, A., \& Olsaker, I. 2019. Alternative subclinical mastitis traits for genetic evaluation in dairy cattle. Journal of Dairy Science, 102, 5323-5329.

Kniha, K., Möhlhenrich, S. C., Bock, A., Ayoub, N., Modabber, A., Hölzle, F., ... Goloborodko, E. 2020. Evaluation of the bactericidal effect of cold atmospheric pressure plasma on contaminated human bone: an in vitro study. British Journal of Oral and Maxillofacial Surgery, 58, 329333.

Laurita, R., Miserocchi, A., Ghetti, M., Gherardi, M., Stancampiano, A., Purpura, V., ... Colombo, V. 2017. Cold Atmospheric Plasma Treatment of Infected Skin Tissue: Evaluation of Sterility, Viability, and Integrity. IEEE Transactions on Radiation and Plasma Medical Sciences, 1, 275-279. 
Lopes, B. B., Beatriz, M., Leite, D. P., Rehder, J., Batista, R. X., \& Puzzi, M. B. 2013. The interactions between non-termal atmospheric pressure plasma and ex-vivo dermal fibroblasts. Procedia Engineering, $59,92-100$.

Lotfy, K., Khalil, S. M., \& El-Raheem, H. A. 2020. Inactivation by helium cold atmospheric pressure plasma for Escherichia coli and Staphylococcus aureus. Journal of Theoretical and Applied Physics, 14, 37-45.

Lunov, O., Zablotskii, V., Churpita, O., Jäger, A., Polívka, L., Syková, E., ... Kubinová, S. 2016. The interplay between biological and physical scenarios of bacterial death induced by non-termal plasma. Biomaterials, 82, 71-83.

Mirani, Z. A., Aziz, M., Khan, M. N., Lal, I., Hassan, N. ul, \& Khan, S. I. 2013. Biofilm formation and dispersal of Staphylococcus aureus under the influence of oxacillin. Microbial Pathogenesis, 61-62, 66-72.

Mohd Nasir, N., Lee, B. K., Yap, S. S., Thong, K. L., \& Yap, S. L. 2016. Cold plasma inactivation of chronic wound bacteria. Archives of Biochemistry and Biophysics, 605, 76-85.

Olatunde, O. O., Benjakul, S., \& Vongkamjan, K. 2019. High voltage cold atmospheric plasma: Antibacterial properties and its effect on quality of Asian sea bass slices. Innovative Food Science and Emerging Technologies, 52, 305-312.

Pandit, S., VRSS, M., Helgadottir, S. H., Westerlund, F., \& Mijakovic, I. 2017. Combination of Cold Atmospheric Plasma and Vitamin $\mathrm{C}$ Effectively Disrupts Bacterial Biofilms. Clinical Microbiology: Open Access, 06. https://doi.org/10.4172/23275073.1000283

Ramdhani, A., Ramdhani, M. A., \& Amin, A. S. 2014. Wriing a Literature Review Research Paper: A step-by-step Approach. The Journal of Applied Behavioral Science, 03, 47-56.

Ren, Q., Liao, G., Wu, Z., Lv, J., \& Chen, W. 2020. Prevalence and characterization of Staphylococcus aureus isolates from subclinical bovine mastitis in southern Xinjiang, China. Journal of Dairy Science, 103, 3368-3380.

Sakudo, A., Yagyu, Y., \& Onodera, T. 2019. Disinfection and sterilization using plasma technology: Fundamentals and future perspectives for biological applications. International Journal of Molecular Sciences, 20. https://doi.org/10.3390/ijms20205216

Sarron, V., Ries, D., Vandamme, M., Robert, E., Sobilo, J., Gosset, D., ... Pape, A. Le. 2012. non-termal plasma. 2194, 21852194.

Srivastava, A. K., \& Kumaresan, A. 2015. Mastitis In Dairy Animal: Current Concepts And Future Concerns. Mastitis in dairy animals: An Update, 25-39.

Thana, P., Wijaikhum, A., Poramapijitwat, P., Kuensaen, C., Meerak, J., Ngamjarurojana, A., ... Boonyawan, D. 2019. A compact pulse-modulation cold air plasma jet for the inactivation of chronic wound bacteria: development and characterization. Heliyon, 5, e02455.

Tian, Y., Sun, P., Wu, H., Bai, N., Wang, R., Zhu, W., ... Liu, F. 2010. Inactivation of Staphylococcus aureus and Enterococcus faecalis by a direct-current, cold atmospheric-pressure air plasma microjet. Journal of Biomedical Research, 24, 264269.

Toba, F. A., Akashi, H., Arrecubieta, C., \& Lowy, F. D. 2011. Role of biofilm in Staphylococcus aureus and Staphylococcus epidermidis ventricular assist device driveline infections. The Journal of Thoracic and Cardiovascular Surgery, 141, 1259-1264.

Yadav, D. K., Adhikari, M., Surendra, K., Ghimire, B., Han, I., Kim, M., \& Choi, E. 2020. Cold atmospheric plasma generated reactive species aided inhibitory effects on human melanoma cells : an in vitro and in silico study. Scientific Reports, 1-15.

Zhang, R., Han, Q., Xia, Y., \& Li, S. 2017. Plasma jet array treatment to improve the hydrophobicity of contaminated HTV silicone rubber. Plasma Science and Technology, 19. https://doi.org/10.1088/2058-6272/aa7c16 
Zhou, R., Zhang, X., Bi, Z., Zong, Z., Niu, J., Song, Y., ... Yang, S. 2015. Inactivation of Escherichia coli cells in aqueous solution by atmospheric-pressure $\mathrm{N} 2, \mathrm{He}$, air, and $\mathrm{O} 2$ microplasmas. Applied and Environmental Microbiology, 81, 52575265.

Ziuzina, D., Boehm, D., Patil, S., Cullen, P. J., \& Bourke, P. 2015. Cold plasma inactivation of bacterial biofilms and reduction of quorum sensing regulated virulence factors. PLOS ONE, 10, 1-21. 